\title{
CREATING CHARACTER BUILDING AGAINST DRUGS ABUSE ON YOUTH ORGANIZATION
}

\author{
Eko Tama Putra SARATIAN ${ }^{*}$, Asep RISMAN ${ }^{2}$, Anees Janee ALI ${ }^{3}$, Fatchur ROHMAN ${ }^{4}$, Yanto RAMLI ${ }^{5}$, \\ and Mochamad SOELTON ${ }^{6}$ \\ 1,2,5,6 Universitas Mercu Buana, Indonesia \\ ${ }^{3}$ SOM University Sains Mayasi \\ ${ }^{4}$ Brawijaya University, Indonesia \\ *eko.tama@mercubuana.ac.id
}

\begin{abstract}
One of the things that has always been a problem in society and requiring special attention is drug abuse. Drugs (short for Narcotics, Psychotropic and other dangerous Addictive Substances) are materials/substances which, when entered into the human body, either physically or Oral/drink, inhaled, or injected, can change thoughts, moods or feelings, and behavior of a person. Drugs can cause physical and psychological dependence (addiction). This community service activity is carried out Community participation in the form of socializing the impact of drug abuse in the community is one of the comprehensive countermeasures. Pre-experimental research methods and types of field research with counseling and mentoring approaches character to youth organization (Karang Taruna). The activity is the increasing knowledge about the impact of drug abuse in the community by optimizing information technology-based. The youth problems were obtained during the activities, then the problem solving was presented at the end of the activity. The results of the activity showed that the youth organization had understood the dangers of drugs abuse for their character building. In addition, they were eager to inform the results of activities to the other friends. As the educational institution that is very close to their environment, University of Mercubuana is expected to continue to give guidance and support for the adolescents' activities.
\end{abstract}

Keywords: Addiction, Character Building, Drugs

\section{BACKGROUND}

One of the things that has always been a problem in society and requiring special attention is drug abuse. Drugs (short for Narcotics, Psychotropics and other dangerous Addictive Substances) are materials/substances which, when entered into the human body, either physically or Oral/drink, inhaled, or injected, can change thoughts, moods or feelings, and behavior of a person. Drugs can cause physical and psychological dependence (addiction).

The same holds true for our responses to the world drug problem. To be effective, balanced solutions to drug demand and supply must be rooted in evidence and shared responsibility. This is more important than ever, as illicit drug challenges become increasingly complex, and the COVID-19 crisis and economic downturn threaten to worsen their impacts, on the poor, marginalized and vulnerable most of all. Some 35.6 million people suffer from drug use disorders globally. While more people use drugs in developed countries than in developing country, and wealthier segments of society have a higher prevalence of drug use, people who are socially and economically disadvantaged are more likely to develop drug use disorders.

Crime is an extraordinary crime that is of concern to all countries in the world, because Narcotics can damage a generation of a country. Currently, the world is being hit by the COVID-19 pandemic, which greatly affects all systems and joints of human life, even causing millions of people to die. The COVID-19 pandemic has also had a major impact on the emergence of new modes of illicit drug trafficking in the world.

In the 2020 UNODC World Drug Report, it is recorded that around 269 million people in the world abuse drugs (study in 2018). This number is 30\% more than in 2009 with the number of drug addicts recorded at more than 35 million people (third booklet of the World Drugs Report, 2020). UNODC also released a global phenomenon where as of December 2019 it was reported that more than 950 types of new substances had been discovered. Meanwhile in Indonesia, based on data from the National Narcotics Agency (BNN) Laboratory, so far, 83 NPS have been detected, of which 73 NPS are included in Permenkes No. 22 of 2020.

Adolescence is a period of transition between childhood and adulthood, which begins at the time of sexual maturity between the ages of 11 or 12 years up to 20 years. Adolescent developmental stages have tasks to be completed. Adolescents usually feel pressure to they conform to the norms and expectations of the group Adolescents are not able to carry out their duties well they tend to consider life to be suffering, unpleasant and do things such as: self-harm, run away from life and family, get involved in free sex, alcohol users, and further involved in the world of narcotics, psychotropics, illegal drugs and other addictive substances. Adolescence and early adulthood are an important period of transitions. It is a time of physical and psychological development, with changes occurring in the brain, and of cognitive and emotional development. For some, it is also a time of increased vulnerability to the initiation of drug use. Adolescence (12-17 years of age) is the critical risk period for the initiation of substance use. Within the population aged 15-64, peak levels of drug use are seen among those aged 18-25. This situation is observed in countries in most regions and for most drug types

Narcotics, Psychotropics and other Addictive Substances (Drugs) which are commonly called narcotics are a 
type of drug necessary drugs/substances. Narcotics and psychotropics is a drug or material that is useful in the field of treatment, health services, and development science, and on the other hand can create a very detrimental dependence if used without control, supervision strict and thorough (Yamin, 2012).

The drug dependence can be interpreted as a condition that encourages someone to take illegal drugs repeatedly or continuously. If someone does not use it, he will feel addicted (sakau) which results in an even uncomfortable feeling. Even worse he will have the feeling of pain (Joseph, 2004).

Dealing with abuse problems drugs require cooperation from the parties government and society. There are five forms ways to deal with abuse drugs, namely: promotive, preventive, curative, rehabilitative and repressive (Hanifah dan Unayah, 2011).

According to Siswanto Sunarso (2010) ignorance of the younger generation on drugs as well as personality fluctuations and availability Drugs are the main problem in the fight against drugs or narkotics. By hence, the supply variable with requests must be handled at once.

Besides that, the impact of narcotics abuse according to the National Narcotics Agency (2010), narcotics can be divided into 3 types, namely:

1. Depressant, that is something which suppresses the central nervous system and reduces the functional body so that the user feels numb; it can even make the users to be asleep and self-defeats. When overdosed, it can lead to death. The depressant drug types include opioda, various derivatives such as morphine, and heroin. The present popular example is the Putaw.

2. Stimulants, something which stimulates body functions and increase excitement as well as awareness. Stimulant types include: Caffeine, Cocaine, and Amphetamine. The examples that are now often used are the Shabu and the Ecstasy.

3. Hallucinogens, the main effect of which is changing the perspective or having hallucinations. The hallucinogens mostly come from the plants such as mescaline which is from cactus and psilocybin which is from mushrooms. In addition there are also those that are mixed in the laboratory such as the LSD. The most widely used is marijuana.

From the formulation of the main problem, the importance of the following issues is explained:

1. The Importance of Basic Understanding of the Definition, the Types and the Impact of Drugs

The basic understanding of the meaning of drugs and their types and their impact on the younger generation as the hope of the nation and the state is very important and urgent. Narcotics is an abbreviation of the narcotics, the psychotropic substances, and the addictive substances. Drugs are medicine, the ingredients, the substances that are drunk / smoked / swallowed, or injected and it can cause dependence and affect the work of the brain, as well as the vital functions of other organs (the heart, the blood circulation, the breathing, etc.) Narcotics are substances or drugs derived from plants or non-plants, both synthetic and semisynthetic which cause a decrease or change in consciousness and eliminate or reduce the pain and they can cause dependence (Law No.27 / 1997) Meanwhile, according to $\mathrm{WHO}$ what is meant by the definition of this drug definition is a substance which, if inserted into the body, will affect physical and / or psychological function (except food, water, or oxygen).

The danger of drugs for the addicts (young generation) is very much and if it is not immediately stopped the habit of consuming drugs, this will worsen the health status of the users themselves slowly but surely, and certainly it can endanger the survival of this nation in the future. Youth as a generation that is expected to be the nation's successor, the more fragile the day is undermined by the addictive substances of neurological destruction, so that the young man cannot think clearly. As a result, the generation of hope for a strong and intelligent nation will only remain a memory. The target age of drug users is the student age, which ranges from 11 to 24 years. This indicates that the dangers of drugs can target our students at any time. The effects of drug use can be in various forms, including the following: 1) Causing a decrease or even change in consciousness, 2) Eliminating the senses, 3) Reducing to relieve pain, 4) Adding dependency / addiction. The greatest danger of drugs for health is the effect of the drug dependence itself. Because with the bad effects caused to drug addicts is the desire to always use it repeatedly.

2. The importance of "Nation and Personal Character Building" in the Early Prevention of Drug Abuse Efforts

The values of life that are given are the character and the good character building programs that are integrated with the entire learning process of the students, starting from their home, their school, their extra-curricular activities, their social activities, and other self-development activities. The value education will perfect the formal education of the students get through the transfer of the knowledge and the skills in school.

It is increasingly recognized that the transfer of knowledge and skills for the students without prioritizing value transfer will only give birth to the students who are skillfully cognitive and skillful, but their fundamental weaknesses in interpreting and applying life values, including: the importance of respect for the parents and the teachers, respect for older people, the discipline, the enthusiasm for learning, the identity, the future vision, the achievement motivation, the cooperation, the willingness to help others, the self-integrity, and a number of other positive characters needed for success.

In building a value-based school culture that is the central mission of the education at this time, various 
approaches to character and character education are needed, both with those that are integrated with the student learning curriculum and with the specific approaches that are given with certain methods. Specific approaches with certain methods are carried out in the form of training using the experiential learning methods. This motivational seminar given to SMK PGRI 5 Pegadungan, Kalideres, West Jakarta students was a stimulus, and became meaningful when the students who took part in the training were committed to practicing it in the study and the daily life. Therefore, this value training was designed in such a way as to help students who were trained to have a strong reflective attitude from every action in the learning process experienced, both at school, in the family, in the social environment, in the community, within the nation, and the country.

This value building training in the character building used a heroic leadership approach based on the four pillars, namely: self-awareness, responsiveness, love, and a burning spirit.

The impact of narcotics abuse on a person depends on the type of narcotics that is used and it will influence the personality of the user and the situation or condition of the user.

In general, the impact of narcotics addiction can be seen in a person's physical, psychological, and social condition.

Physical impact:

1. Disorders of the nervous system (neurological) such as: convulsions, hallucinations, impaired consciousness, and peripheral nerve damage.

2. Disorders of the heart and the blood vessels (cardiovascular) such as: acute infection of the heart muscle, and the circulatory disorders.

3. Skin disorders (dermatological) such as: landings (abscesses), allergies, and eczema.

4. Disorders of the lungs (pulmonary) such as: suppression of respiratory function to difficulty breathing, and hardening of the lung tissue.

5. Frequent headaches, nausea and vomiting, stiffness, increased body temperature, liver wasting, and difficulty sleeping.

6. Impacts on the reproductive health are endocrine disorders, such as: decreased function of reprouduction hormones (estrogen, progesterone, testosterone), and sexual dysfunction.

7. Impacts on the adolescent reproductive health include changes in menstrual periods, menstrual irregularities, and amenorhoe (no menstruation).

8. For the drug users through needles, especially for sharing needles and syringes, the risk is contracting diseases such as hepatitis B, C, and HIV which until now it has no cure.

9. Drug abuse can be fatal when there is an Over Dose that is the drug consumption that exceeds the body's ability to receive it. Over doses can cause death
Psychic Impact:

1. Being Lazy learning, careless, often tense and nervous

2. Losing self-confidence, apathy, fantasy, and suspicion

3. Being agitative, becoming violent, and being brutal behavior

4. Having difficulty concentrating, feeling upset and feeling depressed

5. Having the tendency to hurt yourself, feeling insecure, even commiting suicide

Social Impact:

1. Mental, anti-social and immoral disorders, being isolated by the environment

2. Troubling and becoming a family burden

3. Disrupted education and having a gloomy future.

Physical, psychological, and social impacts are closely related.

The physical dependence will result in tremendous pain (withdrawal) in the event of a drug breakdown (not taking drugs on time) and the psychological encouragement in the form of a very strong desire to consume. These physical and psychological symptoms are also related to social symptoms such as the urge of deceiving parents / friends, stealing, being angry, being manipulative, and others.

\section{METHOD}

This training uses the experiential learning methods with the interactive communication techniques, the dialogue, the discussion, the role play / games, where the participants are introduced to the concept, then directly involved, experiencing, discussing the process and the results of this training to know, understand, realize and be expected to apply the results motivational seminar to help prevent and overcome the drug abuse.

Learning is carried out online using video conferencing (Zoom and Google meet) and using the experiential learning method with interactive communication techniques through video conferencing, dialogue, discussion, role play / games, where participants are introduced provide understanding the importance of student awareness (adolescents) in selfprevention the influence of drugs that can come from friends hanging out at school and at home, the surrounding community, and the mass media that can destroy his future. Practically, this activity is useful for reducing numbers drug use in young people.

This online learning was held in collaboration with the Faculty of Economics and Business, Mercu Buana University (UMB) with Youth organizations located in the West Jakarta area district North Kembangan. UMB helped provide speakers, learning equipment, webinar flyers, pre-post examinations, evaluations, while the organisation helped send representatives of youth members groups,. Online learning participants are 78 participants in this activity. 
Phase 1: Participant's initial test and initial assessment After the opening ceremony and before the material was delivered, participants were asked to fill in the questionnaire using google form as a preliminary test. Initial assessment of the participants is done by filling out the online learning registration form.

Phase 2: Submission of online learning material by the instructor

The online learning material consists of presentations of Complexity Regarding Drugs and the Impact of Abuse and Nation and Personal Character Building as a Model and Strategy to Prevent Drug Abuse.

Phase 3: Post-test and feedback

Before closing, participants are asked to fill in a posttest, and evaluate the event, messages, and impressions of the participants as feedback using google form.

\section{RESULTS AND DISCUSSION}

In general, the results of the community service activities can be seen based on the following components:

1. The success of the target number of e-learning participants. The success of the target number of e-learning participants can be said to be very good. The target number of training participants is 100 people and in the implementation of the service, 78 people (78\%) are attended. This is supported by the role of Youth group organization or Karang Taruna North Kembangan starting from the preparation, distribution of invitations.

2. Participants knowledge before socialization can be identified from the pre-test activities, most of which $65 \%$ have less knowledge compared to those with good knowledge, 35\%, while after socialization the post-test results are mostly good $95 \%$ compared to those with less knowledge 5\% regarding the types of drugs and the impact of drug abuse.

3. Achievement of online learning objectives. The achievement of online learning objectives can be said to be good, reaching 95\%. This community service activity has succeeded in empowering youth organizations at community service locations by motivating them to carry out various positive activities through the use of information technology to avoid deviant associations, especially related to drug abuse.

4. The ability of participants in mastering the material. The ability of participants in mastering the material can be said to be very good (95\%). This is because the youth are familiar with information technology, all participants have social media accounts and are supported by the use of lecture and demonstration methods to improve the ability of participants to absorb the material presented by trainers

Most of the socialization activities about the effects of drugs among adolescents and young people that are followed by the community have increased knowledge were considered successful. This success is not only measured by the four components above, it can also be seen from the satisfaction of participants after participating in the online learning activities.

\section{CONCLUSION}

Based on the discussion in the previous chapters, in this community service activity the following conclusions can be drawn:

First, the government cooperates with educational institutions such as universities. The government holds regular meetings with local community leaders and educational institutions such as Mercubuana University; The purpose of the meeting is to provide enlightenment to public figures, both formal and informal, regarding the role of the community in preventing and controlling and eradicating the circulation of illegal drugs as stipulated in the Narcotics Law and the Psychotropic Law. Encourage the process of building public awareness, building systems, developing guidelines, and training community workers. With the development of information and communication technology, today's technological sophistication, it is hoped that the government and educational institutions can create websites or applications that make it easier for the public to access information about drugs, as well as easy access to contact the authorities in reporting if suspected criminal acts related to drug abuse are suspected found.

Second, Parents must create a family climate that harmonious. Build good communication with youth. Through communication healthy, children will feel comfortable and willing to listen to their parents. Person parents must carry out democratic supervision and assistance not authoritarian. Parents should be aware that today's use of Information technology by young people is a necessity. Teenagers never and cannot escape the bad influence offered through advertising displayed on the smartphone. Therefore, parents do not prohibition of teenagers from using various technological devices, such as smartphones, and laptops, but directing, and encouraging them to use technology for self-development purposes. Besides, busy whatever the parent's job, they must make time for Take care of children because children in their growing period really need love parental love and care. Parents also need to know who their children are with friends and where they are going.

Third, the community. The community also has a role to play in the formation of adolescent character building and personality in the process of self-realization. The community is aware of the conditions that allow teenagers to create explore and develop all talents, capacities and potentials self. People can also control the association and know what they are doing in the social group. The community must reprimand and also advise youth if actions are found deviate from social norms. 


\section{REFERENCE}

Anhari, Ahmad. (2012). Upaya BNN dalam Pencegahan penyalahgunaan narkoba di Kalangan Remaja.

Baker, S. R., Bloom, N., Davis, S. J., \& Terry, S. J. (2020). Covid-induced economic uncertainty (No. w26983). National Bureau of Economic Research.

Fitri M, \& Migunani S. 2014. Sosialisasi dan Penyuluhan Narkoba. Jurnal Inovasi dan Kewirausahaan, 3(2): 72-76

Hanifah, Abu dan Nunung Unayah, 2011. Mencegah dan Menanggulangi Penyahgunaan Napza Melalui Peran Serta Masyarakat. Informasi, Vol. 16 No. 01 Tahun 2013. https://media.neliti.com/ media/publications/52830-ID-mencegah-danmenanggulangipenyalahgunaa.pdf
M Soelton, T Nugrahati, Y Ramli, D Permana, D Kurniawan. 2018. TOWARD THE BEST STRATEGY IN MINIMIZING THE SPREAD OF DRUG USERS. Proceedings International Conference and Community Development 2018. 1 (1), 171-176

Soelton, M., Arief, H., Ramli, Y., Setiawan, M., Rohman, F., \& Mugiono, M. (2019, November). THE BEST STRATEGY FOR FORMING CHILDCARE FROM AN EARLY AGE. In ICCD (Vol. 2, No. 1, pp. 277-280).

Sunarso,Siswanto. 2010. Penegakan Hukum Psikotropika: Dalam Kajian Sosiologi Hukum, Jakarta: PT. Rajagrafindo Perkasa

Yamin, Muhammad. 2012. Tindak Pidana Khusus. Cetakan Pertama. Bandung: Pustaka Setia 